ВОРОНЦОВ Сергей Алексеевич - доктор юридических наук, профессор, и.о. директора научноучебного центра противодействия коррупции Института права и национальной безопасности Российской академии народного хозяйства и государственной службы (РАНХиГС) при Президенте РФ (19571, Россия, г. Москва, пр-кт Вернадского, 82, стр. 2); профессор кафедры процессуального права Южно-Российского института управления - филиала РАНХиГС при Президенте РФ (344002, Россия, г. Ростов-на-Дону, ул. Пушкинская, 70/54; ponedelkov@uriu.ranepa.ru)

ПОНЕДЕЛКОВ Александр Васильевич - доктор политических наук, профессор, заведующий кафедрой политологии и этнополитики, заведующий лабораторией проблем повышения эффективности государственного и муниципального управления Южно-Российского института управления филиала РАНХиГС при Президенте РФ (344002, Россия, г. Ростов-на-Дону, ул. Пушкинская, 70/54; ponedelkov@uriu.ranера.ru); заслуженный деятель науки РФ

\title{
К ДИСКУССИИ ОБ АКТУАЛЬНЫХ ПРОБЛЕМАХ ПРОТИВОДЕЙСТВИЯ КОРРУПЦИИ В СОВРЕМЕННОЙ РОССИИ
}

Аннотация. В представленной вниманию читателей публикации авторы дают информацию об основном содержании и итогах проведенного в онлайн-режиме в г. Ростове-на-Дону и в г. Москве круглого стола с международным участием, посвященного актуальным проблемам борьбы с коррупцией в современной России.

Ключевые слова: коррупция, всероссийский круглый стол, противодействие коррупции, коррупционные риски, Международный день борьбы с коррупцией

9 декабря 2020 г., в Международный день борьбы с коррупцией, состоялся всероссийский круглый стол с международным участием на тему «Актуальные проблемы противодействия коррупции в современной России». Он проводился в режиме онлайн, объединившем две дискуссионные площадки - в Москве и в Ростове-на-Дону. Организаторами дискуссии выступили Институт права и национальной безопасности РАНХиГС, Южно-Российский институт управления - филиал РАНХиГС, общероссийское движение «Сильная Россия», юридический факультет Южного федерального университета, Академия права и национальной безопасности Южного университета (ИУБиП), Управление противодействия коррупции при Губернаторе Ростовской области.

В работе круглого стола приняли участие руководители Ставропольского филиала РАНХиГС, Курганского филиала РАНХиГС, Таганрогского института им. А.П. Чехова - филиала РГЭУ (РИНХ), КЧГУ им. У.Д. Алиева, главные редакторы научных журналов «Гуманитарные, социально-экономические и общественные науки» и «Социум и власть», а также научные работники МГУ им. М.В. Ломоносова, Московского государственного лингвистического университета, ПИУ им. П.А. Столыпина - филиала РАНХиГС, Ростовского государственного экономического университета, Пятигорского государственного университета, Ставропольского государственного педагогического института, Астраханского государственного университета, Уральского федерального университета и других учебных заведений.

С приветственным словом к участникам круглого стола обратился председатель президиума ООО «Офицеры России», Герой России генерал-майор Сергей Липовой, который охарактеризовал масштабы угроз и вызовов, порождаемых коррупцией, а также наметил основные темы для обсуждения в рамках круглого стола. 
Заместитель директора ЮРИУ - филиала РАНХиГС Алексей Баранов отметил, что в современной России проблема противодействия коррупции находится в центре внимания государства и общества, что объясняет регулярное обращение к данному вопросу со стороны компетентных представителей науки, руководителей органов власти и сотрудников правоохранительных структур. Качественная борьба с коррупцией - это основа эффективной системы государственного и муниципального управления и здорового общества в целом. Южно-Российский институт управления проводит обучение по основам противодействия коррупции представителей органов власти и местного самоуправления, ведет информационно-просветительскую работу со студентами, преподаватели вуза выступают экспертами на заседаниях комиссии по конфликту интересов и соблюдению принципов служебного поведения, входят в состав Комиссии по противодействию коррупции при Губернаторе Ростовской области.

Генерал-полковник милиции в отставке, государственный советник юстиции 1-го класса, доктор юридических наук Владимир Колесников в своем докладе проанализировал общие закономерности развития коррупционных процессов в условиях современной цивилизации и высказал ряд предложений, направленных на повышение эффективности противодействия коррупции.

Член Высшего совета движения «Сильная Россия», председатель исполкома общероссийской общественной организации «Офицеры России» генерал-майор в отставке Александр Михайлов в своем выступлении оценил уровень коррупции среди представителей исполнительной власти и народных избранников. В частности, он отметил, что в последнее время к уголовной ответственности привлекают большое число чиновников, но, по странному стечению обстоятельств, большинство из них, несмотря на многомиллионные хищения, взятки, сегодня не отправляются в следственные изоляторы, а находятся под домашним арестом. «А это как раз и показывает, как у нас относятся к коррупции», - заявил А. Михайлов.

В своем выступлении А. Михайлов указал еще на одну актуальную проблему, которая может спровоцировать протестные настроения в обществе, - инициативу депутатов Государственной думы по «закрытию» информации и недопустимости для средств массовой информации и общественности «проникать в жизнь депутатов и государственных служащих».

Заведующий сектором профилактики коррупции Управления противодействия коррупции при Губернаторе Ростовской области Игорь Андронников отметил, что коррупция стоит в одном ряду с терроризмом, экстремизмом, незаконным оборотом наркотиков - не случайно при ее характеристике часто употребляют термин «угроза». Она наносит серьезный ущерб развитию не только государства и общества в целом, но и каждого отдельного гражданина. Коррупция - одна из наиболее острых тем, существующих в российском обществе. Люди теряют веру в законность и справедливость, в обществе начинает формироваться мнение, что все можно решить через коррупционные схемы, а обычному человеку ничего не удастся добиться честным трудом, что, в конечном счете, ведет к росту протестных настроений. Поэтому ключевое значение здесь приобретает профилактика коррупции, к которой следует активно привлекать молодежь.

Заведующий лабораторией проблем повышения эффективности государственного и муниципального управления ЮРИУ РАНХиГС, заслуженный деятель науки РФ, доктор политических наук профессор Александр Понеделков оценил результаты проведенного в 2020 г. сотрудниками лаборатории социологического исследования в форме опроса экспертов в 13 субъектах РФ: 
в Ростовской, Волгоградской, Свердловской, Челябинской, Курганской, Смоленской обл., в Краснодарском, Алтайском, Приморском краях, в республиках Татарстан, Карачаево-Черкессия, Карелия, Коми.

А. Понеделков отметил: «Несмотря на то что в последние годы в антикоррупционную практику внедрены стандарты, позволяющие своевременно выявлять и предупреждать коррупционные риски, эксперты, характеризуя причины коррупции, на первую ранговую позицию поставили ответ "недостаточно строгий контроль за действиями чиновников, их доходами и расходами”. Основной упор сегодня должен быть сделан не на расширении репрессивных мер по отношению к выявленным коррупционерам, а на работе по противодействию коррупции в молодежной среде, на комплексном воспитании у представителей зарождающейся политико-административной элиты и управленцев устойчивого негативного отношения к коррупции на уровне подсознания. Для этого следует использовать весь комплекс средств убеждения и взаимодействия, в т.ч. и религиозных, устанавливающих моральные запреты и ограничения».

По мнению профессора А. Понеделкова, только совместные усилия общества и государства в идеологическом и морально-нравственном воспитании у представителей российской молодежи нетерпимости к природе коррупционной составляющей могут привести к устранению данной угрозы.

Бизнес-омбудсмен в Ростовской области Олег Дереза обратил внимание участников дискуссии на рост коррупционного давления на бизнес. Остановившись на анализе наиболее значимых нарушений коррупционного характера в экономической сфере, О. Дереза высказал конкретные предложения:

- о необходимости внесения изменений в федеральный закон № 44-Ф3 «О контрактной системе в сфере закупок товаров, работ, услуг для обеспечения государственных и муниципальных нужд» в части критериев определения победителей в конкурсах и аукционах;

- об изменении определения стоимости товаров и услуг на момент заключения договора, а не по ценам прошедших периодов, умноженным на коэффициенты, не подкрепленные рыночными реалиями;

- об изменении норм контрольно-надзорных органов в части исключения из них положений, которые прямо не влияют на жизнь и здоровье граждан и являются зачастую устаревшими и избыточными.

Руководитель научно-учебного центра ИПНБ РАНХиГС при Президенте России, доктор юридических наук профессор ЮРИУ РАНХиГС Сергей Воронцов сообщил, что в Ростовской обл. в 2020 г. проведены 11 научно-практических конференций и 9 научно-обучающих мероприятий для государственных и муниципальных служащих. В данных мероприятиях приняли участие более 3000 муниципальных служащих, около 2500 студентов и преподавателей шести высших учебных заведений региона. Как следует из приведенных выше цифр, основной упор в предупредительно-профилактической работе следует сделать:

1) на сфере государственной и муниципальной службы, где в настоящее время фиксируется основное число правонарушений коррупционного характера, так как служащие, в силу своего должностного статуса, наиболее уязвимы со стороны искушений коррупционного характера;

2) на среде студентов высших учебных заведений, которые в ближайшее время вольются в ряды государственных и муниципальных служащих. Соответственно, у молодых специалистов должно быть воспитано отторжение использования коррупционных механизмов и схем в будущей практической деятельности, что, в конечном счете, будет способствовать минимизации уровня коррупции в нашей стране. Следует также учитывать, что обсуждение в 
студенческой среде проблем противодействия коррупции с привлечением квалифицированных экспертов вызывает живой интерес у молодежи и, в конечном счете, усиливает профилактический эффект антикоррупционной работы;

3) на населении области, отдельные представители которого при взаимодействии с органами власти могут выступать как в качестве лиц, у которых вымогают взятки чиновники, так и в качестве лиц, провоцирующих чиновников на получение взятки за решение вопросов коррупционными методами.

С. Воронцов отметил, что в 2021 г. в работу научно-информационного центра будут внесены коррективы. Основное внимание планируется сосредоточить на молодежной аудитории, чтобы с «младых ногтей» формировать в сознании молодых служащих и студентов систему правовых и нравственных запретов и ограничений в целях воспитания внутренней установки личности на исполнение норм антикоррупционного законодательства не под угрозой возможных репрессий за нарушение установленных норм, а в силу личного убеждения.

Заслуженный деятель науки РФ, доктор социологических наук, профессор, заведующий кафедрой общественных связей и медиаполитики, заместитель декана факультета журналистики ИГСУ РАНХиГС Феликс Шарков в своем выступлении сообщил об информационной составляющей коррупционных моделей коммуникации.

Директор Таганрогского института им. А.П. Чехова - филиала РГЭУ (РИНХ) Андрей Голобородько поделился опытом моделирования ландшафта антикоррупционного просвещения молодежи на муниципальном уровне.

Директор Курганского филиала РАНХиГС, кандидат технических наук доцент Валерий Яхонтов остановился на анализе уровня коррупции как индекса развития социума.

Тему коррупционного давления на бизнес в области уголовной юстиции продолжил кандидат юридических наук, заведующий кафедрой уголовного процесса и криминалистики Южного федерального университета Константин Степанов.

Доктор политических наук, главный редактор научного журнала «Социум и власть» Сергей Зырянов выступил с докладом «Проблемы противодействия коррупции в современной России: региональная проекция».

Доктор социологических наук, профессор, главный редактор всероссийского научного журнала «Гуманитарные, социально-экономические и общественные науки» Михаил Попов посвятил свое выступление рискогенному потенциалу коррупции в постсоветском трансформирующемся социуме.

По результатам дискуссии лаборатория проблем повышения эффективности государственного и муниципального управления ЮРИУ РАНХиГС планирует издать второй сборник научных статей по проблемам противодействия коррупции. 
VORONTSOV Sergey Alekseevich, Dr.Sci. (Legal), Professor, Acting Director of the Anti-Corruption Research and Training Center, Institute of Law and National Security, Russian Presidential Academy of National Economy and Public Administration (RANEPA) (bld. 1, 82 Vernadskogo Ave, Moscow, Russia, 119571); Professor of the Chair of Procedure Law, South Russian Institute of Management - Branch of the RANEPA(70/54 Pushkinskaya St, Rostov-on-Don, Russia, 344002; ponedelkov@uriu.ranepa.ru)

PONEDELKOV Aleksandr Vasil'evich, Dr.Sci. (Pol.Sci.), Professor; Head of the Chair of Political Science and Ethnopolitics, Russian Presidential Academy of National Economy and Public Administration (RANEPA) (bld. 1, 82 Vernadskogo Ave, Moscow, Russia, 119571); Head of the Laboratory for Problems of Promotion Efficiency of State and Municipal Administration, South-Russian Institute of Management - Branch of RANEPA (70/54 Pushkinskaya St, Rostov-on-Don, Russia, 344002; ponedelkov@uriu.ranepa.ru); Honored Scientist of the Russian Federation

\section{TO THE DISCUSSION ON THE CURRENT PROBLEMS OF ANTI-CORRUPTION IN MODERN RUSSIA (according to the materials of the Round Table on December 9, 2020)}

\footnotetext{
Abstract. In the publication presented to readers, the authors give information about the main content and results of allRussian roundtable with international participation, conducted online in Rostov-on-Don and in Moscow, dedicated to the current problems of fighting corruption in modern Russia. According to the authors, it is significant that this event is held on the International Anti-Corruption Day, which is a testament to the urgency of the problem not only for our country, but also for the entire world community.
}

Keywords: corruption, all-Russian roundtable, anti-corruption, corruption risks, International Anti-Corruption Day 